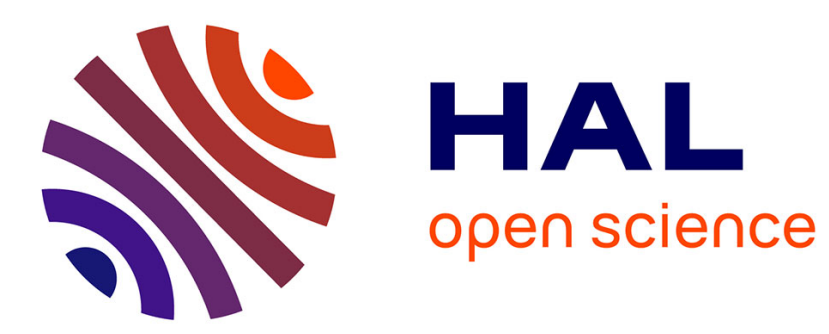

\title{
Evaluation of orally administered valacyclovir in experimentally EHV1-infected ponies
}

\author{
B. Garré, A. Gryspeerdt, S. Croubels, P. de Backer, H. Nauwynck
}

\section{To cite this version:}

B. Garré, A. Gryspeerdt, S. Croubels, P. de Backer, H. Nauwynck. Evaluation of orally administered valacyclovir in experimentally EHV1-infected ponies. Veterinary Microbiology, 2009, 135 (3-4), pp.214. 10.1016/j.vetmic.2008.09.062 . hal-00532506

\section{HAL Id: hal-00532506 https://hal.science/hal-00532506}

Submitted on 4 Nov 2010

HAL is a multi-disciplinary open access archive for the deposit and dissemination of scientific research documents, whether they are published or not. The documents may come from teaching and research institutions in France or abroad, or from public or private research centers.
L'archive ouverte pluridisciplinaire HAL, est destinée au dépôt et à la diffusion de documents scientifiques de niveau recherche, publiés ou non, émanant des établissements d'enseignement et de recherche français ou étrangers, des laboratoires publics ou privés. 


\section{Accepted Manuscript}

Title: Evaluation of orally administered valacyclovir in experimentally EHV1-infected ponies

Authors: B. Garré, A. Gryspeerdt, S. Croubels, P. De Backer, H. Nauwynck

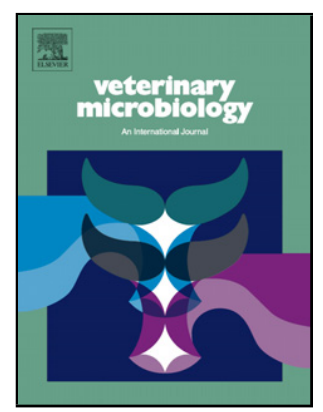

PII:

DOI:

Reference:

To appear in:

Received date:

Revised date:

Accepted date:
S0378-1135(08)00439-2

doi:10.1016/j.vetmic.2008.09.062

VETMIC 4205

VETMIC

$17-6-2008$

$1-9-2008$

$15-9-2008$

Please cite this article as: Garré, B., Gryspeerdt, A., Croubels, S., De Backer, P., Nauwynck, H., Evaluation of orally administered valacyclovir in experimentally EHV1infected ponies, Veterinary Microbiology (2008), doi:10.1016/j.vetmic.2008.09.062

This is a PDF file of an unedited manuscript that has been accepted for publication. As a service to our customers we are providing this early version of the manuscript. The manuscript will undergo copyediting, typesetting, and review of the resulting proof before it is published in its final form. Please note that during the production process errors may be discovered which could affect the content, and all legal disclaimers that apply to the journal pertain. 
1 Evaluation of orally administered valacyclovir in experimentally EHV1-infected ponies.

2

3

4

5

6

10 Shortened running title: Valacyclovir in EHV1-infected ponies

11 Number of words in summary: 262

12 Number of words in text: 4011

13 Number of tables and figures combined: 6

14

$15 *$ Corresponding author: Barbara Garré

16 Department of Pharmacology, Toxicology and Biochemistry

17 Faculty of Veterinary Medicine, Ghent University

18 Salisburylaan 133

199820 Merelbeke, Belgium

20 Phone: +3292647346

$21 \quad$ Fax: +3292647497

22 E-mail: barbara.garre@ugent.be
${ }^{2}$ Laboratory of Virology,

Faculty of Veterinary Medicine, Ghent University, Belgium 


\section{Abstract}

25

The purpose of the current study was to investigate the therapeutic efficacy of valacyclovir against EHV1 in a controlled study. Eight naïve Shetland ponies were inoculated with $10^{6.5}$ $\mathrm{TCID}_{50}$ of the neuropathogenic strain 03P37. Four ponies were treated with valacyclovir at a dosage of $40 \mathrm{mg} / \mathrm{kg}$ bodyweight, three times daily, for five $(\mathrm{n}=2)$ or seven $(\mathrm{n}=2)$ consecutive days, while the other 4 ponies served as untreated controls. The treatment regimen started 1 hour before inoculation. Ponies were monitored daily for clinical signs. At 0, 1, 2, 3, 4, 5, 7, 9, $11,14,17$ and 21 days pi, a nasopharyngeal mucus sample was taken to determine viral shedding. At the same time points, blood was collected and peripheral blood mononuclear cells (PBMC) were isolated to determine viremia. During treatment, blood samples were collected 6 times daily, i.e. just before valacyclovir administration and 1 hour later, to determine the concentration of acyclovir in plasma. Also a nasopharyngeal swab was taken to measure the acyclovir concentration in nasal secretion. No differences could be noticed between valacyclovir treated and untreated ponies. The clinical signs, the viral shedding and the viremia were similar in both groups. Plasma acyclovir concentration could be maintained above the $\mathrm{EC}_{50}$-value of $\mathrm{EHV} 1$ during $50 \%$ of the entire treatment period in valacyclovirtreated ponies. Acyclovir could be detected in nasal swabs at concentrations varying from 50$100 \%$ of the corresponding plasma concentration.

Although sufficiently high acyclovir levels could be reached in plasma and nasal mucus, no effect was seen of the treatment with valacyclovir on clinical signs, viral shedding and viremia of EHV1-infected ponies.

Keywords: EHV1, valacyclovir, experimental infection, therapy 


\section{Introduction}

The use of antivirals in veterinary medicine is currently subject of increasing interest.

51 Cytokines like interferons possess antiviral and anti-oncogenic properties and can therefore be used to treat certain cancers and viral infections. In cats, interferons have been administered for the treatment of feline infectious peritonitis (FIP) (Ritz et al., 2007), feline leukaemia virus (FeLV) and feline immunodeficiency virus (FIV) (de Mari et al., 2004) and feline herpes virus (FHV1) infections (Stiles, 2000; Haid et al., 2007; Gutzwiller et al., 2007).

Besides the use of these biological products, owners and veterinarians take much interest in chemotherapeutics for the treatment of viral infections.. Both in cats and horses, the therapeutic efficacy of several antivirals has been investigated. For FeLV and FIV, the molecules of interest are nucleoside reverse transcriptase inhibitors, e.g. zidovudine, abacavir, lamivudine and stampidine (Hartman, 1998; Arai et al., 2002; Uckun et al., 2003). Nucleoside analogues like acyclovir, valacyclovir, idoxuridine, trifluridine and vidarabine are the antiviral products mostly used to treat FHV1-infections (Owens et al., 1996; Nasisse et al., 1997; Galle, 2004). These analogues are structurally similar to the nucleosides of which DNA and RNA consist. They are incorporated into the viral DNA, thereby terminating the growing viral DNA chain. In horses, influenza- and herpesviruses are common viral pathogens. Both rimantidine (Rees et al., 1999) and oseltamivir (Yamanaka et al., 2006) could ameliorate the clinical signs of influenza virus infections. In contrast to the cat, there are no studies to evaluate the therapeutic efficacy of nucleoside analogues to treat herpesvirus infections.

EHV1 may result in several clinical syndromes in horses. The respiratory disease is usually silent (Foote et al., 2006), but a new sporadic form of EHV1 results in respiratory distress and even death of the affected horses (Del Piero and Wilkins, 2001). EHV1 can also cause 
abortion storms can occur on a premise, which are associated with great economic losses

74

75

76

(Allen and Bryans, 1986). Finally, neurological disorders due to EHV1 have been reported with increasing frequency (McCartan et al., 1995; Friday et al., 2000; van Maanen et al., 2001; Stierstorfer et al., 2002; van der Meulen et al., 2003; Henninger et al., 2007). During an outbreak many horses can exhibit neurological disorders with devastating consequences. The use of the nucleoside analogue acyclovir has been described during outbreaks of neonatal foal disease (Murray et al., 1998) and neurological disorders (Friday et al., 2000; van der Meulen et al., 2003; Wilkins, 2004; Henninger et al., 2007). However, the benefit of these treatments is difficult to evaluate since there were no untreated control animals included.

There are several reasons to use acyclovir for the treatment of EHV1-infected horses. Acyclovir has proven to be effective against abortigenic and neuropathogenic strains of EHV1 in vitro (Garré et al., 2007a). It is no longer protected by a patent and generic products are available, so the expenses to treat horses during an outbreak are reasonable. Acyclovir has been used in humans for almost 30 years and has proven to be safe, even in neonates (Hintz et al., 1982) and pregnant women (Baker, 1999), which makes it attractive to use in pregnant mares and foals. The pharmacokinetics of acyclovir have also been described in horses (Wilkins et al., 2005; Bentz et al., 2006; Garré et al., 2007b). However, the oral bioavailability of acyclovir is low. Oral administration of the prodrug, valacyclovir, is associated with higher bioavailability (Garré et al., 2007b) resulting in higher plasma concentrations. A recent study in horses and ponies demonstrated that multiple dosing of valacyclovir every $8 \mathrm{~h}$ results in plasma concentrations exceeding the $\mathrm{EC}_{50}$-value of $\mathrm{EHV} 1$ during the majority of the treatment period (Garré et al., submitted).

The purpose of the current study was to investigate the therapeutic efficacy of valacyclovir against EHV1 in a controlled infection experiment, by investigating clinical symptoms, viral shedding and viremia of valacyclovir-treated and untreated ponies. 


\section{2. Materials and methods}

100

\section{$101 \quad 2.1 \quad \underline{\text { Virus }}$}

102 The Belgian EHV1-strain 03P37 was used for the experimental inoculation. This strain 103 was isolated from the peripheral blood mononuclear cells (PBMC) of a paralytic horse in 1042003 (van der Meulen et al., 2003). The strain has been typed as neuropathogenic in

105 cooperation with the Animal Health Trust in the United Kingdom (Nugent et al., 2006). The

106 virus used for inoculation was at the $6^{\text {th }}$ passage; 2 passages were performed in rabbit kidney

107 cells (RK13) and the 4 subsequent passages in equine embryonic lung cells (EEL).

108

109

\section{$2.2 \quad \underline{\text { Animals }}$}

110 Eight Shetland ponies were used in the study (A-H). Seven of the eight ponies were 111 younger than 8 months since the third incisor was not yet erupted. The other pony (A) was 112 approximately 2 years of age. Two females (D, F) and six males were included. None of the 113 ponies had been vaccinated prior to their arrival. Prior to the experiment, ponies were 114 monitored for 4 weeks. The rectal temperature was measured daily and complement115 dependent seroneutralization (SN)-tests and immunoperoxidase monolayer assays (IPMA) 116 were performed weekly to determine EHV-specific antibody titres. None of the ponies had a

117 raise in rectal temperature during this observation period which indicates that none of them 118 experienced an infection. None of the ponies had detectable EHV-specific antibody titres on 119 any occasion $(\mathrm{SN}<2$, IPMA $<10)$.

120 All ponies were housed in isolation stables. They were fed daily with a commercial, complete feed. Drinking water and hay were supplied ad libitum. 


\section{$123 \quad 2.3 \quad$ Experimental inoculation}

124 Each pony was inoculated oronasally with $20 \mathrm{ml}$ of a virus suspension containing $10^{6.5}$ 125 tissue culture infectious dose ${ }_{50}\left(\mathrm{TCID}_{50}\right)$. Ten $\mathrm{ml}$ were administered intranasally $(5 \mathrm{ml}$ per 126 nostril) and $10 \mathrm{ml}$ were inoculated orally. The virus titre was confirmed by titration of the

127 inoculum. The ponies were inoculated at 8 am, i.e. 1 hour after the first valacyclovir 128 administration.

\section{$130 \quad 2.4 \quad$ Valacyclovir administration}

131 Four of the eight ponies were treated with valacyclovir (VACV), while the other four 132 ponies served as untreated controls. The treatment consisted of $40 \mathrm{mg}$ of valacyclovir $/ \mathrm{kg}$ 133 body weight, administered three times daily, i.e. at $7 \mathrm{am}, 3 \mathrm{pm}$ and $11 \mathrm{pm}$ for five (pony A, B)

134 or seven (pony C, D) consecutive days. The doses were prepared identically for all horses by 135 mixing the calculated amount of valacyclovir with apple sauce. The mixture was administered 136 orally using a $60 \mathrm{ml}$ syringe.

137

\subsection{Clinical observation}

139 Following virus inoculation, the ponies were monitored daily for three weeks for clinical

140 signs via physical examination and measurement of rectal temperature. A rectal temperature 141 of $\geq 38.5^{\circ} \mathrm{C}$ was regarded as fever. During clinical examination, nasal discharge (serous, 142 mucous or purulent), lymph node swelling, ocular discharge, tachypnoea, coughing and 143 nervous system disorders were investigated. The breathing frequency was counted to evaluate 144 breathing problems. Several tests were performed to evaluate nervous system disorders: 145 walking the horse in a straight line, walking on and off a step, walking the horse in teight 146 circles, pulling the horse's tail and backing the horse. 


\subsection{Virological examination}

A nasopharyngeal mucus sample and $40 \mathrm{ml}$ of heparinised blood were taken at $0,1,2,3,4$, $5,7,9,11,14,17$ and 21 days post inoculation (d pi).

The nasopharyngeal samples were collected using a swab with a length of $40 \mathrm{~cm}$ that was inserted through the nostrils up to the nasopharynx. Immediately after collection, the swabs were immersed in transport medium containing phosphate buffered saline supplemented with $10 \%$ fetal bovine serum, $1000 \mathrm{U} / \mathrm{ml}$ penicillin, $1 \mathrm{mg} / \mathrm{ml}$ streptomycin and $0.5 \mathrm{mg} / \mathrm{ml}$ kanamycin. EHV1 was titrated in the nasopharyngeal secretions. Therefore, the nasopharyngeal swabs were vortexed in the transport medium, the medium was centrifuged and the supernatant was titrated on monolayers of RK13 cells.

Peripheral blood mononuclear cells (PBMC) were isolated from the heparinised blood by density centrifugation on Ficoll-Paque (Pharmacia Biotech AB, Uppsala, Sweden). The cells were washed three times with phosphate buffered saline and resuspended in complete medium containing 2/1 MEM and RPMI 1640 supplemented with 10\% fetal calf serum, 0.05 mM 2mercapto-ethanol, $100 \mathrm{U} / \mathrm{ml}$ penicillin, $0.1 \mathrm{mg} / \mathrm{ml}$ streptomycin, $0.1 \mathrm{mg} / \mathrm{ml} \mathrm{kanamycin}, 0.3$ $\mathrm{mg} / \mathrm{ml}$ glutamine, $1 \%$ non-essential amino-acids 100x (GibcoBRL, Life Technologies, Paisley, UK) and $1 \mathrm{mM}$ sodium pyruvate. For co-cultivation, the cells were seeded on RK13 monolayers. The monolayers were placed at $37^{\circ} \mathrm{C}$ and $5 \% \mathrm{CO}_{2}$. After 36 hours of incubation, the number of plaques was counted. For pony C, D and E, 2 different co-cultures were made. Normal medium was added to the one co-culture, while acyclovir at a concentration of 4 $\mu \mathrm{g} / \mathrm{ml}$ was added to the other co-culture to investigate whether acyclovir could exert an effect on the transmission of virus from infected PBMC to target cells.

\subsection{Acyclovir quantification}


172 In order to determine peak and trough concentrations in plasma, $5 \mathrm{ml}$ of blood were

173 collected into heparinized blood collection tubes (Venoject, Terumo, Leuven, Belgium) at 7

174 am, $3 \mathrm{pm}$ and $11 \mathrm{pm}$ just before valacyclovir administration (trough), and at $8 \mathrm{am}, 4 \mathrm{pm}$ and

$17512 \mathrm{pm}$ (peak), during five (day 0-4 pi; pony A, B) or seven days (day 0-6 pi; pony C, D) of

176 treatment. The next three days (day 5-7 pi for pony A, B; day 7-9 pi for pony C, D), blood

177 samples were collected at $7 \mathrm{am}, 3 \mathrm{pm}$ and $11 \mathrm{pm}$ to determine the elimination phase. Plasma

178 was immediately harvested by centrifugation at $400 \mathrm{~g}$ for 10 minutes and was frozen at $-70^{\circ} \mathrm{C}$

179 until assayed.

180 The nasopharyngeal mucus samples were taken daily at $4 \mathrm{pm}$ during valacyclovir

181 treatment. The nasopharyngeal samples were collected using a swab with a length of $40 \mathrm{~cm}$

182 inserted through the nostrils up to the nasopharynx. Immediately after collection, the cotton of

183 the swab was cut off and put in an Eppendorf. Then, swabs were centrifuged for 10 minutes at

$18410.000 \mathrm{~g}$ to collect the nasal fluid which was transferred to another Eppendorf and stored at -

$18570^{\circ} \mathrm{C}$ until assayed.

186 The acyclovir concentration was determined using high-performance liquid 187 chromatography combined with tandem mass spectrometry (LC-MS/MS), based on Maes et

188 al. (in press). The unbound concentration of acyclovir was obtained by a simple 189 deproteinization step of the sample using a Microcon ${ }^{\circledR}$ filter. Ganciclovir was used as an 190 internal standard.

\section{$192 \quad 2.8 \quad$ Serological examination}

193 The SN titre was determined at $0,7,14$ and $21 \mathrm{~d}$ pi by means of a complement-dependent

194 SN-test. Two-fold serum dilutions were prepared in duplicate rows of 96-well microtiter 195 plates using MEM as diluent and mixed with 300 TCID $_{50}$ of the EHV1-isolate Arabica. After 19623 hours of incubation at $37^{\circ} \mathrm{C}$ and $5 \% \mathrm{CO}_{2}, 25 \mu 1$ of unheated guinea pig serum was added to 
197

198

199

200

201

202

203

204

205

206

207

208

209

210

211

212

213

214

215

216

217

218

219

220

221

each well as a source of complement. Plates were then incubated for an additional hour and the content of each well was subsequently transferred to a monolayer of RK13 cells. The monolayers were incubated at $37^{\circ} \mathrm{C}$ and $5 \% \mathrm{CO}_{2}$ and after 7 days examined for cytopathic effect. The SN titre was calculated as the reciprocal value of serum dilution that neutralized the cytopathic effect in $50 \%$ of the wells.

In case no detectable SN titre was observed, serum samples were tested using a more sensitive IPMA. RK13 cells were seeded in 96-well microtiter plates, grown to confluency and inoculated with $10^{3}$ TCID $_{50}$ of the EHV1-isolate 97P70. After $28 \mathrm{~h}$, cells were washed, dried at $37^{\circ} \mathrm{C}$ for $1 \mathrm{~h}$ and stored at $-20^{\circ} \mathrm{C}$ until use. Plates were then thawed and subsequently fixed with $4 \%$ paraformaldehyde and a solution containing $1 \%$ hydrogen in methanol. Following extensive washing, serial 2-fold dilutions of the sera were added and cells were incubated for $1 \mathrm{~h}$ at $37^{\circ} \mathrm{C}$. Then, cells were incubated with peroxidase-labeled goat anti-horse antibodies (Jackson ImmunoResearch Laboratories Inc., PA, USA). After 1 hour, a substrate solution of 3-amino-9-ethylcarbazole in $0.05 \mathrm{M}$ acetate buffer with $0.05 \%$ hydrogen was added to each well. After 20 minutes of incubation at $37^{\circ} \mathrm{C}$, the substrate solution was replaced with an acetate buffer to block the enzymatic staining reaction. The IPMA titre was calculated as the reciprocal value of highest serum dilution that induced visual staining of infected RK13 cells, as determined by light microscopy.

\subsection{Statistical analysis}

The Student's t-test was used to demonstrate possible differences in body temperature, duration of pyrexia, the area under the body temperature-time curve (AUC), duration of viral shedding, viral titres, duration of viremia and the number of infected PBMC in co-cultivation. Differences with $\mathrm{P}<0.05$ were considered significant. 
222

223

224

225

226

227

228

229

230

231

232

233

234

235

236

237

238

239

240

241

242

243

244

245

246

\section{Results}

\subsection{Clinical observation}

The clinical signs as observed in the EHV1-inoculated ponies are summarized in Table 1. They were mild and consisted mostly of nasal discharge and swelling of the lymph nodes. Nasal discharge occurred for 14 days at most, varying from serous to purulent. Four ponies had ocular discharge for a short period of time. Swelling of the mandibular lymph nodes lasted for the entire observation period $(21 \mathrm{~d} \mathrm{pi})$ in most ponies. The retropharyngeal lymph nodes could not be palpated but a painful reaction of the pony upon palpation indicated swelling. Tachypnoea and coughing occurred in 3 and 5 ponies, respectively. Also a short period of dullness could be noticed. None of the ponies developed nervous system disorders, such as ataxia or paresis. The temperature curves are presented in Figure 1. On $2 \mathrm{~d}$ pi, all ponies had fever, however valacyclovir treated ponies had a significantly lower body temperature (average $\left.=38.8^{\circ} \mathrm{C}\right)$ than non-treated ponies $\left(\right.$ average $\left.=39.9^{\circ} \mathrm{C}\right)$. Fever lasted for 5 or 6 days in most ponies, except for pony E (2-3 d pi) and G which was only pyretic for one day ( $2 \mathrm{~d}$ pi). There was no difference in duration of pyrexia between both groups. Also no difference in the AUC of body temperature could be noted.

\subsection{Virus isolation from the upper respiratory tract}

The results of virus isolation from the nasopharyngeal swabs are shown in Table 2. Five ponies started viral shedding on $1 \mathrm{~d}$ pi. All ponies shed virus on $2 \mathrm{~d}$ pi. Virus shedding lasted until $7 \mathrm{~d}$ pi in all untreated ponies. In valacyclovir treated ponies, viral shedding lasted until 9 or $11 \mathrm{~d}$ pi in 3 ponies, while pony $\mathrm{C}$ shed virus for 21 days. However, this difference in duration of viral shedding was not significant. Valacyclovir treated and untreated ponies had similar virus titres from $1 \mathrm{~d}$ pi up to $7 \mathrm{~d}$ pi. 


\subsection{Viremia}

249 The numbers of infected PBMC as determined by co-cultivation are presented in Table 3.

250 Infected PBMC were detected by co-cultivation between 3 and $9 \mathrm{~d}$ pi, 1 and $14 \mathrm{~d}$ pi, 1 and 17

$251 \mathrm{~d}$ pi, 2 and $17 \mathrm{~d}$ pi in the valacyclovir-treated ponies $\mathrm{A}, \mathrm{B}, \mathrm{C}$ and $\mathrm{D}$, respectively. In the

252 untreated ponies, cell-associated viremia was detected between 2 and $11 \mathrm{~d}$ pi, 2 and $9 \mathrm{~d}$ pi, 7

253 and $9 \mathrm{~d}$ pi, 2 and $14 \mathrm{~d}$ pi in pony $\mathrm{E}, \mathrm{F}, \mathrm{G}$ and $\mathrm{H}$, respectively. There was no difference in the

254 duration of viremia between both groups. There were also no differences between treated and untreated ponies in the number of infected PBMC determined by co-cultivation.

There was no difference in the number of infected PBMC between normal co-cultures and co-cultures supplemented with acyclovir.

\subsection{Serological response to experimental inoculation}

The complement-dependent SN titres are shown in Table 4. A clear seroconversion was observed at 14 or $21 \mathrm{~d}$ pi, except for pony $\mathrm{G}$ which developed very low levels of antibodies even after $21 \mathrm{~d}$ pi.

\subsection{Acyclovir concentration}

The unbound plasma concentration versus time curve is presented in Figure 2. Plasma concentrations could be maintained above the $\mathrm{EC}_{50}$-value of $1.7 \mu \mathrm{g} / \mathrm{ml}$, i.e. $\mathrm{EC}_{50}$ of an isolate highly susceptible to acyclovir, for $76 \%$ of the treatment period and above the $\mathrm{EC}_{50}$-value of $3.0 \mu \mathrm{g} / \mathrm{ml}$, i.e. $\mathrm{EC}_{50}$ of an isolate less susceptible to acyclovir, for $46 \%$ of the treatment period.

Acyclovir could be detected in nasal mucus samples at concentrations varying from 0.5 $\mu \mathrm{g} / \mathrm{ml}$ to $6.5 \mu \mathrm{g} / \mathrm{ml}$. The concentrations in nasal mucus samples varied from 50 to $100 \%$ of the

271 corresponding plasma concentrations. 


\section{Discussion}

The purpose of the current study was to investigate whether valacyclovir, the oral prodrug of acyclovir, is effective in the treatment of EHV1-infected horses. Eight Shetland ponies were used in this study. Seven of them were 6 months of age. None of them had detectable EHV-specific antibody titres prior to the study. The use of weanling horses (five to nine months of age), free of EHV1 neutralizing antibodies, is a common tool in EHV1 research

280 (Cornick et al., 1990; Matsumura et al., 1996; Heldens et al., 2001). The foals were 281 monitored for 4 weeks after arrival. During this observation period, no fever was recorded, no virus was isolated from nasopharyngeal swabs and no EHV-specific antibodies were detected on any occasion. This strongly indicated that all foals were EHV1 negative prior to the experiment. This was enforced by the absence of a quick serological booster reaction shortly after challenge. Working with naïve animals is important to minimise the effect of immune status on the clinical and virological outcome.

287 The foals were inoculated oronasally with the EHV1-isolate 03P37, which was isolated 288 from PBMC of a paralytic horse during an outbreak in a Belgian riding school in 2003 (van der Meulen et al., 2003). During this outbreak, neurological disorders were observed in $15 \%$ of all horses. The disorders consisted mainly of ataxia and paralysis of hind limb and tail, but

291 also cerebral disorders, such as blindness, torticollis and severe apathy were observed. The 292 mortality during the outbreak was $10 \%$, so we can conclude that this EHV1-isolate is highly 293 pathogenic. Despite the high virulence of the isolate, the clinical symptoms observed in our 294 infection study were mild and consisted of pyrexia, nasal discharge and swelling of lymph nodes. Ocular discharge and respiratory symptoms such as tachypnoea and coughing were also observed. A short period of dullness could be noticed in six of the eight inoculated 
ponies. Dullness was also noted by Kydd et al. (1994) who exposed Welsh Mountain ponies

298 to the EHV1 strain Ab4, which was obtained from a quadriplegic mare affected during an 299 outbreak of neurological disease in 1980 (Crowhurst et al., 1981). The same strain was used

300 by Smith et al. (1996) where all five infected mares showed dullness. Paralysis did not occur

301 nor in one of these studies, nor in our study. In contrast, a study of Mumford et al. (1994)

302 where mares were intranasally inoculated with the Ab4 strain, resulted in neurological disease

303 in some animals. Development of neurological disorders appears to be dependent on several

304 factors, including the animal's age and sex, and, in mares, the stage of their reproductive cycle

305 (McCartan et al., 1995). The severity of the disease may also be influenced by the physical

306 condition of the host, the immune status of the host, and the pathogenic potential of the strain

307 involved (Nugent et al., 2006).

308 Four ponies were treated with valacyclovir, while the other four ponies served as untreated

309 controls. The treatment was started 1 hour before inoculation as it has been shown that, after

310 oral administration of valacyclovir, maximal plasma concentrations are reached after

311 approximately 1 hour (Garré et al., 2007b). The dosage regimen consisted of $40 \mathrm{mg} / \mathrm{kg}$ every

3128 hours. We previously demonstrated that this dosage regimen was sufficient to maintain

313 plasma concentrations in horses and ponies above the $\mathrm{EC}_{50}$-value of EHV1 during the

314 majority of the treatment period (Garré et al., submitted). It has been suggested that maximal

315 efficacy is reached when the length of time that the acyclovir concentration remains above the

$316 \mathrm{EC}_{50}$ is more than $50 \%$ of treatment period (Tod et al., 2001). Also in this study, plasma

317 concentrations could be maintained above the $\mathrm{EC}_{50}$-value of $1.7 \mu \mathrm{g} / \mathrm{ml}$ for $76 \%$ of the

318 treatment period and above the $\mathrm{EC}_{50}$-value of $3.0 \mu \mathrm{g} / \mathrm{ml}$ for $46 \%$ of the treatment period. The

319 isolate used in this study, 03P37, is susceptible to acyclovir in vitro at a concentration of 3.0

$320 \mu \mathrm{g} / \mathrm{ml}$ (Garré et al., 2007a), so this dosage regimen should have been effective to exert an

321 antiviral effect. However, no differences could be noted between both groups of ponies in 
322 clinical signs, viral shedding and viremia, except for the peak body temperature at $2 \mathrm{~d}$ pi,

323 where valacyclovir treated ponies had a lower body temperature than untreated ponies

$324(\mathrm{P}<0.05)$.

325 Acyclovir could be detected in nasal mucus at concentrations varying from $50-100 \%$ of the 326 corresponding plasma concentrations. This is in contrast with our earlier report where the 327 acyclovir concentration in nasal mucus of healthy horses was only $7.5 \%$ of the corresponding 328 plasma concentration (Garré et al., submitted). This may be due to the fact that the ponies in 329 the present study were infected with EHV1 and experienced nasal discharge. Infection of the 330 respiratory tract causes hyperaemia (Allen and Bryans, 1986), which may influence the 331 distribution of acyclovir into nasal mucus.

332 Although acyclovir was present in the nasal mucus, no effect could be demonstrated on 333 nasal shedding of the virus. Valacyclovir-treated ponies did not show a shorter period of viral

334 shedding or decreased viral titres in comparison with untreated ponies. It even seemed that 335 valacyclovir-treated ponies experienced a longer period of viral shedding; however this 336 difference was not significant. One pony, C, shed virus for 21 days. Normally, nasal shedding 337 is observed from 1 day up till 7,8 or 9 days after inoculation. However, nasal swabs may be 338 virus positive up till 14 days after inoculation (Gibson et al., 1992; Heldens et al., 2001; van 339 der Meulen et al., 2006). Patel et al. (1982) also found virus in nasal swabs up to $21 \mathrm{~d}$ pi in a 340 foal inoculated with a paresis isolate. Most researchers only sample the nasopharynx during 341 the first 10 (Gleeson and Coggins, 1980; Chong and Duffus, 1992; Mumford et al., 1994) or

34214 days after inoculation (Heldens et al., 2001). On these occasions, we can not draw any 343 conclusion about the duration of nasal shedding as the latest collected sample is still virus 344 positive at the end of the observation period (Chong and Duffus, 1992; Heldens et al., 2001).

345 This implies that three weeks of quarantine for horses arriving on a farm is the absolute 346 minimum. 
There was no difference between valacyclovir-treated ponies and untreated ponies in the

348 duration of viremia or the number of infected PBMC. During cell-associated viremia, 98\% of

349 EHV1-infected PBMC do not show viral envelope proteins on their surface (van der Meulen

350 et al., 2006). Moreover, viral envelope proteins are also undetectable intracellular. Only the

351 immediate-early protein and at least one early protein, ICP22 (regulatory protein), are present

352 in the cytoplasm (van der Meulen et al., 2006). This indicates that EHV1-infected PBMC

353 circulating during cell-associated viremia are in an early phase of infection. It is possible that

354 during cell-associated viremia, EHV1 replication is restricted to early events and that

355 transcription of the remaining viral genome is postponed until a certain trigger occurs. Since

356 acyclovir targets the DNA polymerase where it acts as a chain terminator, no effect on the

357 number of infected PBMC is expected.

358 Earlier findings by Smith et al., (2001, 2002) indicated that activation of adhesion

359 molecules on both leukocytes and endothelial cells play a key role in the transfer of virus

360 from infected PBMC to endothelial cells. This adhesion of infected PBMC to susceptible cells

361 may provide the activation signal that triggers later events. Secondary replication in

362 endothelial cells at the target sites results in vasculitis with secondary ischemia and

363 haemorrhage resulting in the several symptoms (Edington et al., 1986; 1991). Acyclovir may

364 be able to exert an effect on the secondary virus replication and subsequently, be able to

365 prevent abortion and neurological disorders. However, the results of the co-cultivation

366 supplemented with acyclovir are in conflict to this theory. No difference was found in the

367 number of infected PBMC in normal co-cultures and co-cultures supplemented with

368 acyclovir. This indicates that acyclovir can not prevent the transmission of virus from infected

369 PBMC to target cells and that acyclovir can not inhibit the secondary replication in

370 experimentally EHV1-infected horses. 
371 This study shows that acyclovir and its oral prodrug valacyclovir are not effective in

372 EHV1-infected horses.

373

374 Acknowledgement

375

376 The authors thank C. Boone for titrations, C. Bracke for isolation of PBMC and

377 performing SN-tests. We also thank N. Desmet for the chromatographic analysis of the 378 samples.

379 
380

381

382

383

384

385

386

387

388

389

390

391

392

393

394

395

396

397

398

399

400

401

402

403

404

405

406

407

408

409

\section{References}

Allen, G.P., Bryans, J.T., 1986. Molecular epizootiology, pathogenesis and prophylaxis of equine herpesvirus-1 infections. Prog. Vet. Microbiol. Immunol. 2, 78-144.

Arai, M., Earl, D.D., Yamamoto, J.K., 2002. Is AZT/3TC therapy effective against FIV infection or immunopathogenesis? Vet. Immunol. Immunopathol., 85, 189-204.

Baker, D.A., 1999. The use of antiviral medications in the treatment of herpes simplex virus infections of women. Int. J. Fertil. 44, 227-233.

Bentz, B.G., Maxwell, L.K., Erkert, R.S., Royer, C.M., Davis, M.S., MacAllister, C.G., Clarke, C.R., 2006. Pharmacokinetics of acyclovir after single intravenous and oral administration to adult horses. J. Vet. Intern. Med. 20, 589-594.

Chong, Y.C., Duffus, W.P.H., 1992. Immune responses of specific pathogen free foals to EHV-1 infection. Vet. Microbiol. 32, 215-228.

Cornick, J., Martens, J., Martens, R., Crandell, R., McConnell, S., Kit, S., 1990. Safety and efficacy of a thymidine kinase negative equine herpesvirus-1 vaccine in young horses. Can. J. Vet. Res. 54, 260-266.

Crowhurst, F.A., Dickinson, G., Burrows, R. 1981. An outbreak of paresis in mares and geldings associated with equid herpesvirus 1. Vet Rec. 109, 527-528.

Del Piero, F., Wilkins, P.A., 2001. Pulmonary vasculotropic EHV-1 infection in equids. Vet. Pathol. 38, 474475.

de Mari, K., Maynard, L., Sanquer, A., Lebreux, B., Eun, H.M., 2004. Therapeutic effects of recombinant feline interferon-omega on feline leukaemia virus (FeLV)-infected and FeLV/feline immunodeficiency virus (FIV)coinfected symptomatic cats. J. Vet. Intern. Med. 18, 477-482. 
411 Edington, N., Bridges, C.G., Patel, J.R., 1986. Endothelial cell infection and thrombosis caused by equid 412 herpesvirus-1: equine stroke. Arch. Virol. 90, 111-124.

413

414 Edington, N., Smyth, B., Griffiths, L., 1991. The role of endothelial cell infection in the endometrium, placenta 415 and foetus of equid herpesvirus 1 (EHV-1) abortions. J. Comp. Pathol. 104, 379-387.

416

417 Foote, C.E., Love, D.N., Gilkerson, J.R., Wellington, J.E. Whalley, J.M., 2006. EHV-1 and EHV-4 infection in 418 vaccinated mares and their foals. Vet. Immunol. Immunopathol. 111, 41-46.

419

420

Friday, P.A., Scarratt, W.K, Elvinger, F., Timoney, P.J., Bonda, A., 2000. Ataxia and paresis with equine herpesvirus type 1 infection in a herd of a riding school horses. J. Vet. Intern. Med. 14, 197-201.

422

Galle, L.E., 2004. Antiviral therapy for ocular viral disease. Vet. Clin. North Am. Small Anim. Pract. 34, 639653.

Garré, B., van der Meulen, K., Nugent, J., Neyts, J., Croubels, S., De Backer, P., Nauwynck, H., 2007a. In vitro susceptibility of 6 isolates of equine herpes virus 1 to acyclovir, ganciclovir, cidofovir, adefovir, PMEDAP and foscarnet. Vet. Microbiol. 16, 43-51.

429

430 Garré, B., Shebany, K., Gryspeerdt, A., Baert, K., van der Meulen, K., Nauwynck, H., Deprez, P., De Backer, P., 431 Croubels, S., 2007b. Pharmacokinetics of acyclovir after intravenous infusion of acyclovir and after oral 432 administration of acyclovir and its prodrug valacyclovir in healthy adult horses. Antimicrob. Agents Chemother. $51,4308-4314$.

Garré, B., Baert, K., Nauwynck, H., Deprez, P., De Backer, P., Croubels, S. Multiple oral dosing of valacyclovir in horses and ponies. J. Vet. Pharmacol. Ther. (submitted).

437

438 Gibson, J.S., Slater, J.D., Awan, A.R., Field, H.J., 1992. Pathogenesis of equine herpesvirus-1 in specific 439 pathogen-free foals: primary and secondary infections and reactivation. Arch. Virol. 123, 351-366. 
441 Gleeson, L.J., Coggins, L., 1980. Response to pregnant mares to equine herpesvirus 1 (EHV1). Cornell Vet. 70, $442 \quad 391-400$.

443

444 Gutzwiller, M.E., Brachelente, C., Taglinger, K., Suter, M.M., Weissenböck, H., Roosje, P.J., 2007. Feline 445 herpes dematitis treated with interferon omega. Vet. Dermatol. 18, 50-54.

446

447

Haid, C., Kaps, S., Gönczi, E., Hässig, M., Metzler, A., Spiess, B.M., Richter, M., 2007. Pretreatment with feline interferon omega and the course of subsequent infection with feline herpesvirus in cats. Vet. Ophtalmol. 10, 278284.

450

Hartmann, K., 1998. Feline immunodeficiency virus infection: an overview. Vet. J. 155, 123-137.

452

453

Heldens, J.G.M., Hannant, D., Cullilane A.A., Prendergast, M.J., Mumford, J.A., Nelly, M., Kydd, J.H.,

Weststrate, M.W., van den Hoven, R., 2001. Clinical and virological evaluation of the efficacy of an inactivated

EHV1 and EHV4 whole virus vaccine (Duvaxyn EHV $\left.{ }_{1,4}\right)-$ Vaccination/challenge experiments in foals and

pregnant mares. Vaccine 19, 4307-4317.

457

Henninger, R.W., Reed, S.M., Saville, W.J., Allen, G.P., Hass, G.F., Kohn, C.W., Sofaly, C., 2007. Outbreak of neurological disease caused by equine herpesvirus-1 at a university equestrian center. J. Vet. Intern. Med. 21, $157-165$

461

Hintz, M., Connor, J.D., Spector, S.A., Blum, M.R., Keeney, R.E., Yeager, A.S., 1982. Neonatal acyclovir pharmacokinetics in patients with herpes virus infections. Am. J. Med. 73, 210-214.

Kydd, J.H., Smith, K.C., Hannant, D., Livesay, G.J., Mumford, J.A., 1994. Distribution of equid herpesvirus-1 466 (EHV-1) in the respiratory tract of ponies: implications for vaccination strategies. Equine Vet. J. 26, 466-469.

468 Maes, A., Garré, B., Desmet, N., van der Meulen, K., Nauwynck, H., De Backer, P., Croubels, S., 2008. 469 Determination of acyclovir in horse plasma and body fluids by high-performance liquid chromatography 
470

471

472

473

474

475

476

477

478

479

480

481

482

483

484

485

486

487

488

489

490

491

492

493

494

495

496

497

498

499

combined with fluorescence detection and heated electrospray ionization tandem mass spectrometry. Biomed. Chromatrogr. In press.

Matsumura, T., O’Callaghan, D.J., Kondo, T., Kamada, M., 1996. Lack of virulence of the murine fibroblast adapted strain, Kentucky A (KyA), of equine herpesvirus type 1 (EHV-1) in young horses. Vet. Microbiol. 48, $353-365$.

McCartan, C.G., Russell, M.M., Wood, J.L.N., Mumford, J.A., 1995. Clinical, serological and virological characteristics of an outbreak of paresis and neonatal foal disease due to equine herpesvirus-1 on a stud farm. Vet. Record 136, 7-12.

Mumford, J.A., Hannant, D., Jessett, D.M., O’Neill, T., Smith, K.C., Ostlund, E.N. Abortigenic and neurological disease caused by experimental infection with equid herpesvirus-1, in: Nakajima H., Plowright W. (Eds) Equine Infectious Diseases VII, Proc. 7th Int. Conference of Equine Infectious Diseases, Newmarket, UK, 1994, pp. $261-275$

Murray, M.J., Del Piero, F., Jeffrey, S.C., Davis, M.S., Furr, M.O., Dubovi, E.J., Mayo, J.A., 1998. Neonatal equine herpesvirus type 1 infection on a thoroughbred breeding farm. J. Vet. Intern. Med. 12, 36-41.

Nasisse, M.P., Dorman, D.C., Jamison, K.C., Weigler, B.J., Hawkins, E.C., Stevens, J.B., 1997. Effects of valcyclovir in cats infected with feline herpesvirus 1. Am. J. Vet. Res. 58, 1141-1144.

Nugent, J., Birch-Machin, I., Smith, K.C., Mumford, J.A., Swann, Z., Newton, J.R., Bowden, R.J., Allen, G.P., Davis-Poynter, N., 2006. Analysis of equid herpesvirus 1 strain variation reveals a point mutation of the DNA polymerase strongly associated with neuropathogenic versus nonneuropathogenic disease outbreaks. J.Virol. 80, 4047-4060.

Owens, J.G., Nasisse, M.P., Tadepalli, S.M., Dorman, D.C., 1996. Pharmacokinetics of acyclovir in the cat. J. Vet. Pharmacol. Ther. 19, 488-490. 
Patel, J.R., Edington, N., Mumford, J.A., 1982. Variation in cellular tropism between isolates of equine

501

502

503

504

505

506

507

508

509

510

511

512

513

514

515

516

517

518

519

520

521

522

523

524

525

526

527

528

529

herpesvirus-1 in foals. Arch. Virol. 74, 41-45.

Rees, W.A., Harkins, J.D., Lu, M., Holland, R.E. jr, Lehner, A.F., Tobin, T., 1999. Chambers T.M., Pharmacokinetics and therapeutic efficacy of rimantidine in horses experimentally infected with influenza virus A2. Am. J. Vet. Res. 60, 888-894.

Ritz, S., Egberink, H., Hartmann, K., 2007. Effect of feline interferon-omega on the survival time and quality of life of cats with feline infectious peritonitis. J. Vet. Intern. Med. 21, 1193-1197.

Smith, K.C., Mumford, J.A., Lakhani, K., 1996. A comparison of equid herpesvirus-1 (EHV-1) vascular lesions in the early versus late preganr equine uterus. J. Comp. Path. 114, 231-247.

Smith, D.J., Hamblin, A.S., Edington, N., 2001. Infection of endothelial cells with equine herpesvirus-1 (EHV-1) occurs where there is activation of putative adhesion molecules: a mechanism for transfer of virus. Equine Vet. J. $33,138-142$.

Smith, D., Hamblin, A., Edington, N., 2002. Equid herpesvirus 1 infection of endothelial cells requires activation of putative adhesion molecules: an in vitro model. Clin. Exp. Immunol. 129, 281-287.

Stierstorfer, B., Eichhorn, W., Schmahl, W., Brandmuller, C., Kaaden, O.R., Neubauer, A., 2002. Equine herpesvirus type 1 (EHV-1) myeloencephalopathy: a case report. J. Vet. Med. B Inf. Dis. Vet. Public Health 49, $37-41$.

Stiles, J., 2000. Feline herpesvirus. Vet. Clin. North Am. Small Anim. Pract. 30, 1001-1014.

Tod, M., Lokiec, F., Bidault, R., De Bony, F., Petitjean, O., Aujard, Y. \& the Acyclovir Pediatric French Group, 2001. Pharmacokinetics of oral acyclovir in neonates and in infants: a population analysis. Antimicrob. Agents and Chemother. 45, 150-157. 
530 Uckun, F.M., Chen, C., Samuel, P., Pendergrass, S., Venkatachalam, T.K., Waurzyniak, B., Qazi, S., 2003. In

531 vivo antitretriviral activity of stampidine in chronically feline immunodeficiency virus-infected cats. Antimicrob.

532 Agents Chemother. 47, 1233-1240.

533

534 van Maanen, C., Sloet van Oldruiterborgh-Oosterbaan, M.M., Damen, E.A., Derksen, A.G., 2001. Neurological

535 disease associated with EHV-1 infection in a riding school: clinical and virological characteristics. Equine Vet. J.

$536 \quad 33,191-196$.

537

538 van der Meulen, K.M., Vercauteren, G., Nauwynck, H.J., Pensaert, M.B., 2003. A local epidemic of equine 539 herpesvirus 1-induced neurological disorders in Belgium. Flem. Vet. J. 72, 366-372.

540

541 van der Meulen, K., Caij, B., Pensaert, M., Nauwynck, H., 2006. Absence of viral envelope proteins in equine 542 herpesvirus 1-infected blood mononuclear cells during cell-associated viremia. Vet. Microbiol. 113, 265-273.

543

544 Wilkins, P.A., Acyclovir in the treatment of EHV-1 myeloencephalopathy. American College of Veterinary 545 Internal Medicine, 22 ${ }^{\text {nd }}$ Annual Meeting, Minneapolis, MN, 2004, pp 170-172.

546

547 Wilkins, P.A., Papich, M., Sweeney, R.W., 2005. Pharmacokinetics of acyclovir in adult horses. J. Vet. Em. Crit.

548 Care 15, 174-178.

549

550 Yamanaka, T., Tsujimura, K., Kondo, T., Hobo, S., Matsumura, T., 2006. Efficacy of oseltamivir phosphate to 551 horses inoculated with equine influenza A virus. J. Vet. Med. Sci. 68, 923-928. 


\section{Figure legends:}

554

555 Figure 1. Body temperature in valacyclovir-treated and untreated ponies following 556 experimental inoculation with EHV1.

557

558 Figure 2. Unbound plasma acyclovir concentration versus time curve (mean $+\mathrm{SD})$ during

559 and after valacyclovir administration ( $40 \mathrm{mg} / \mathrm{kg}$ body weight, 3 times daily) in ponies treated

560 for $5(\mathrm{~A}, \mathrm{~B})$ or 7 days $(\mathrm{C}, \mathrm{D})$

561 : average of ponies A, B, C, D; o: average of ponies A, B; $\square$ : average of ponies C, D 562 


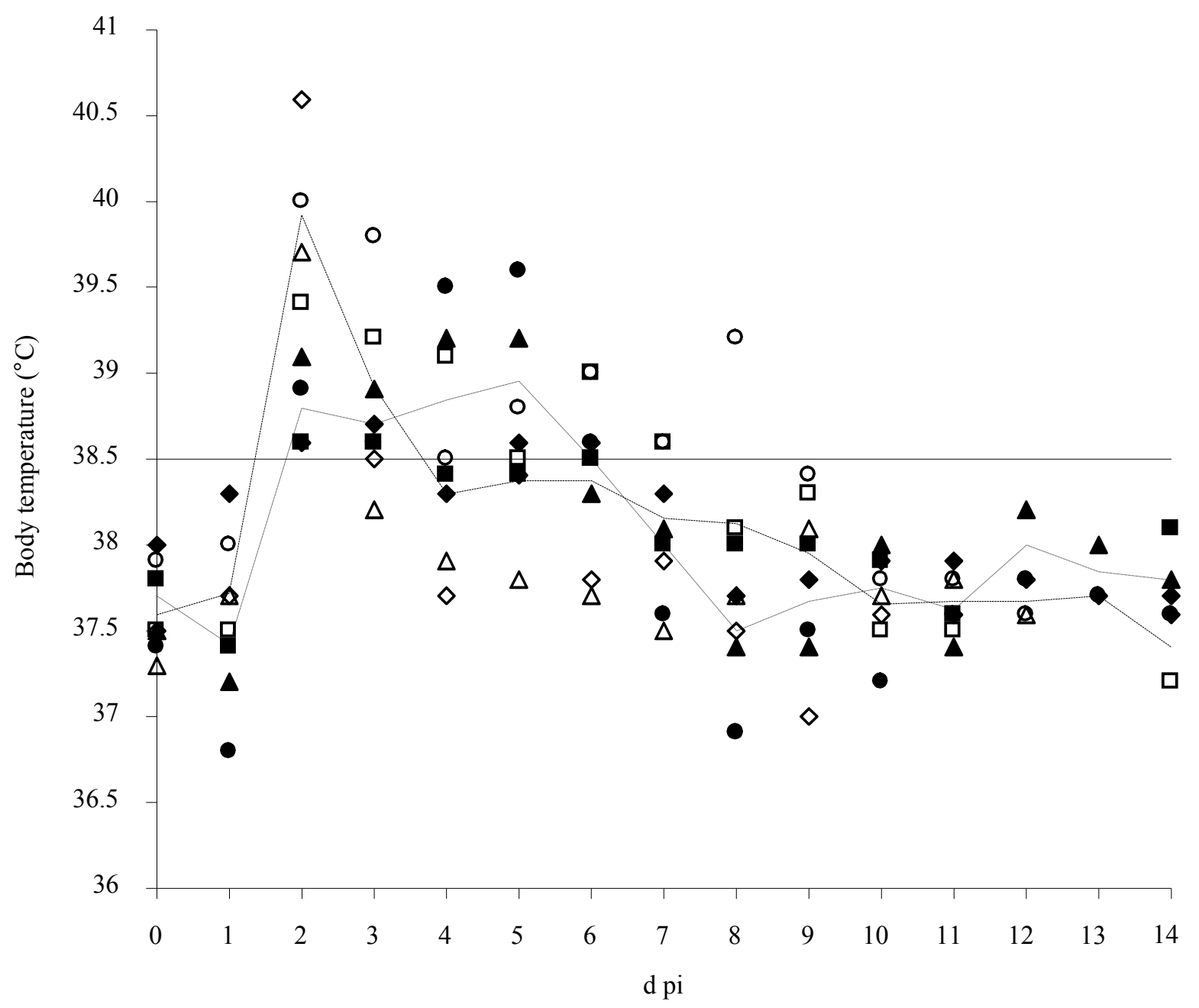

Valacyclovir-treated ponies

Untreated ponies

$\begin{array}{llll}\text { - } & \mathrm{A}(5 \mathrm{~d}) & \diamond & \mathrm{E} \\ \text { - } & \mathrm{B}(5 \mathrm{~d}) & \boldsymbol{B} & \mathrm{F} \\ \text { - } & \mathrm{C}(7 \mathrm{~d}) & \Delta & \mathrm{G} \\ & \mathrm{D}(7 \mathrm{~d}) & \circ & \mathrm{H} \\ & \text { average } & & \text { average } \\ & \text { fever }\left(\geq 38.5^{\circ} \mathrm{C}\right) & & \end{array}$

Figure 1. Body temperature in valacyclovir-treated and untreated ponies following experimental inoculation with EHV1. 


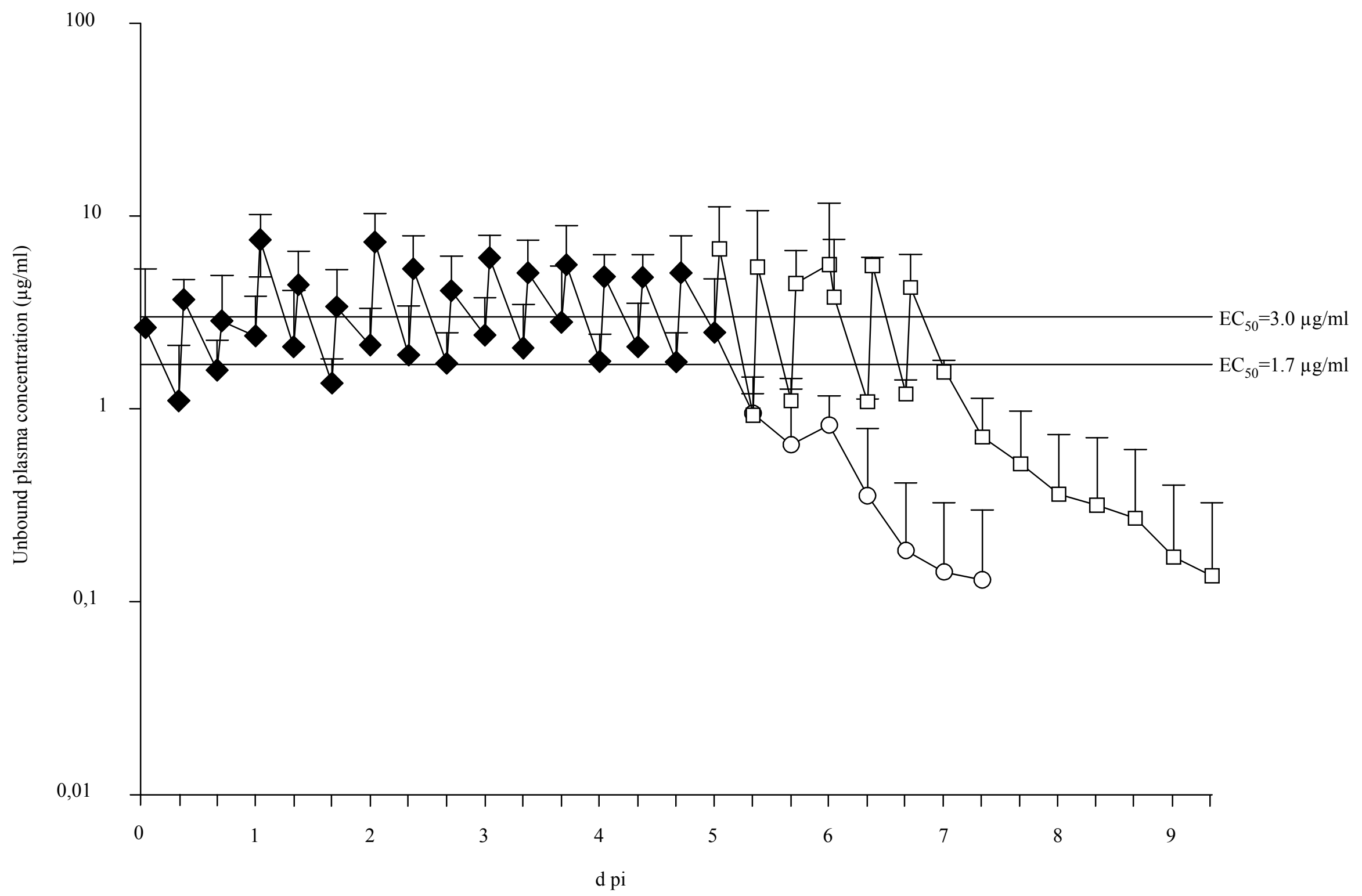

Figure 2. Unbound plasma acyclovir concentration versus time curve (mean $+\mathrm{SD})$ during and after valacyclovir administration (40 $\mathrm{mg} / \mathrm{kg}$ body weight, 3 times daily) in ponies treated for 5 (A, B) or 7 days $(\mathrm{C}, \mathrm{D})$

: average of ponies A, B, C, D; $\mathrm{O}$ : average of ponies A, B; $\square$ : average of ponies C, D 
Table 1. Clinical signs in valacyclovir-treated and untreated ponies following experimental inoculation with EHV1.

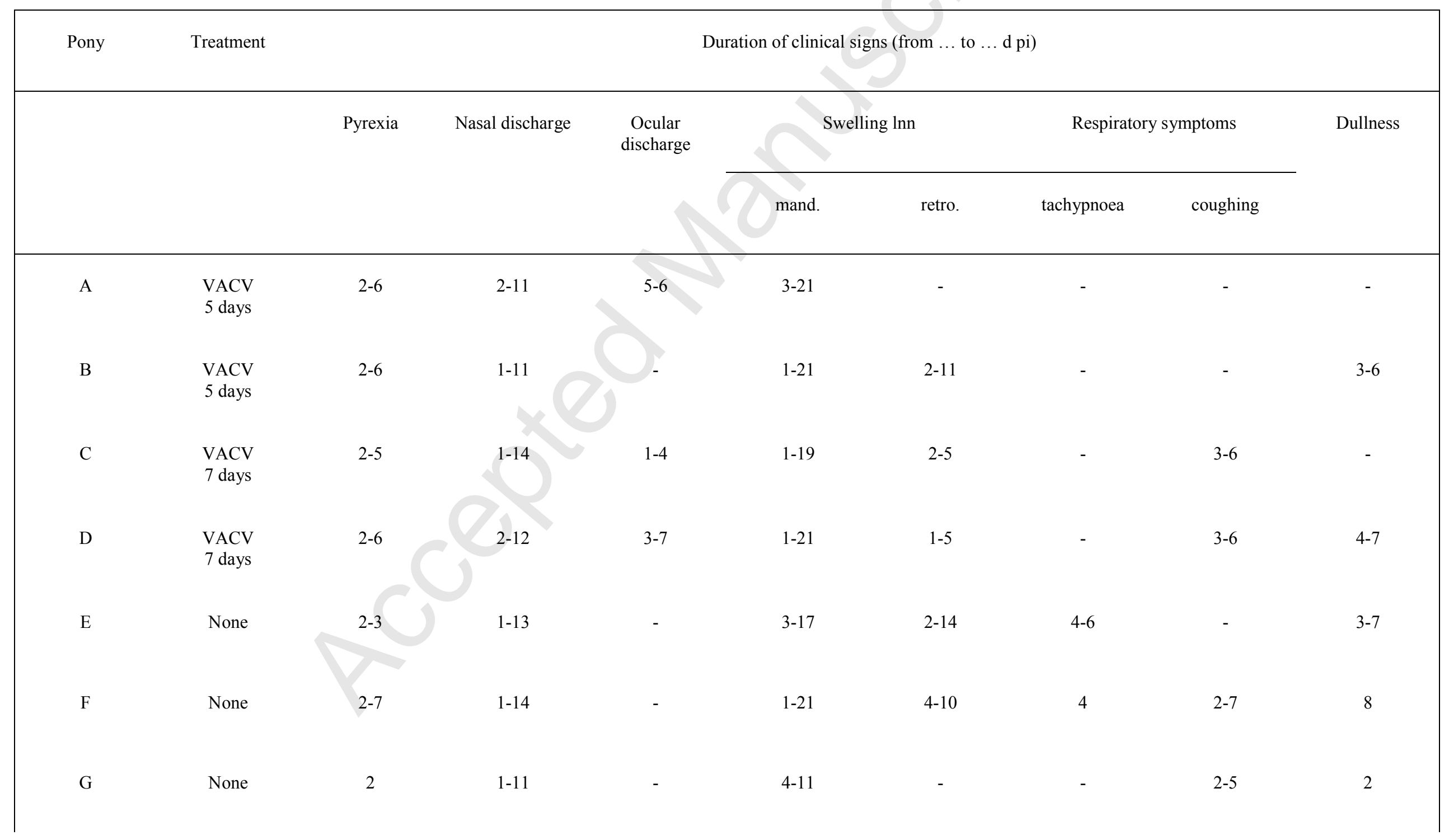


Table 2. Virus shedding in valacyclovir-treated and untreated ponies following experimental inoculation with EHV1.

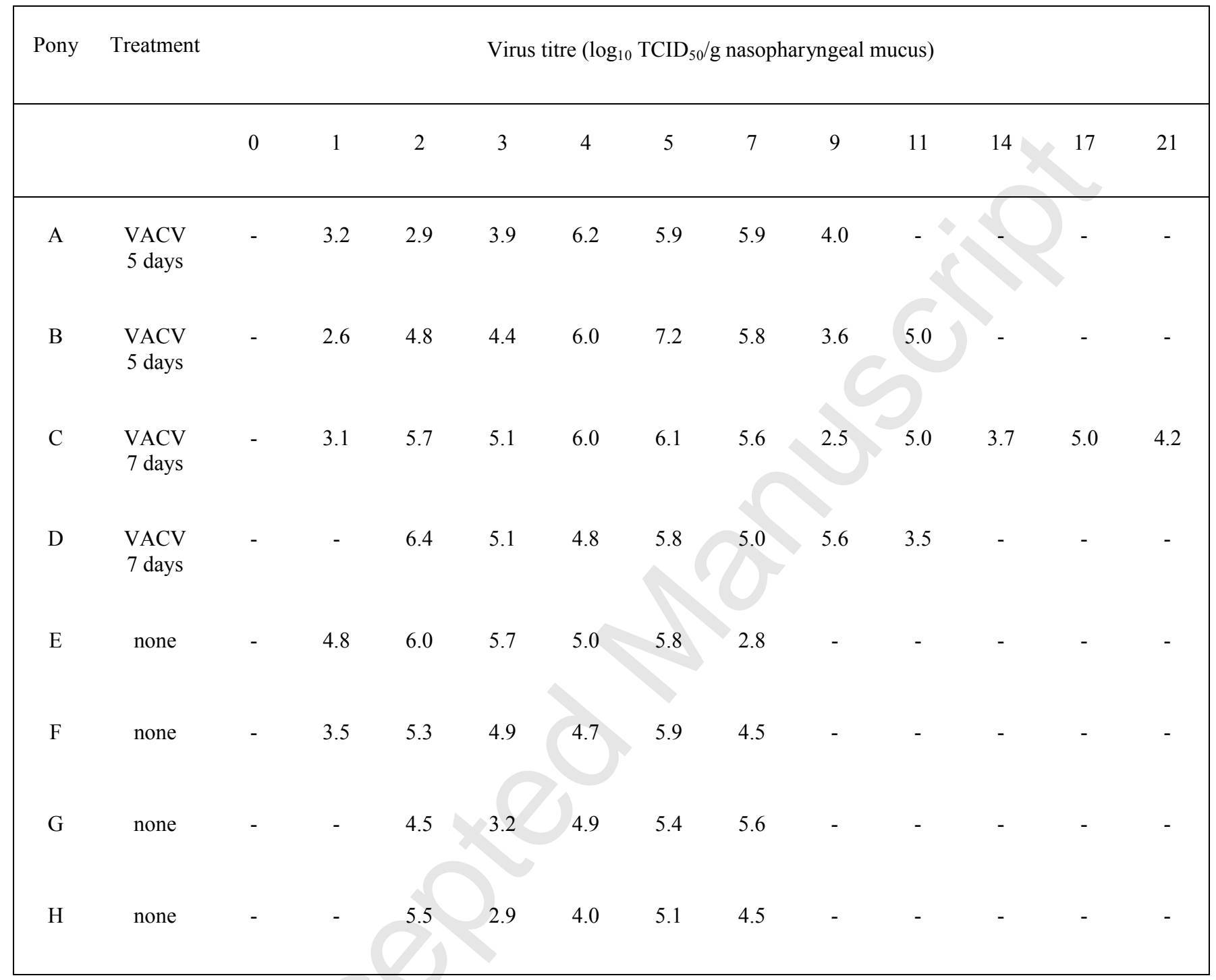

EHV: equine herpesvirus; TCID: tissue culture infectious dose; VACV: valacyclovir; $(-):<2.2 \log _{10} \mathrm{TCID}_{50} / \mathrm{g}$ nasopharyngeal mucus 
Table 3. Cell-associated viremia in valacyclovir-treated and untreated ponies following experimental inoculation with EHV1.

\begin{tabular}{|c|c|c|c|c|c|c|c|c|c|c|c|c|c|}
\hline \multirow[t]{2}{*}{ Pony } & \multirow[t]{2}{*}{ Treatment } & \multicolumn{12}{|c|}{ Number of infected cells able to transmit virus $/ 10^{7} \mathrm{PBMC}$ (co-cultivation) at ... d pi } \\
\hline & & 0 & 1 & 2 & 3 & 4 & 5 & 7 & 9 & 11 & 14 & 17 & 21 \\
\hline A & $\begin{array}{l}\text { VACV } \\
5 \text { days }\end{array}$ & - & - & - & 1 & 3 & 10 & 5 & 1 & - & & & - \\
\hline B & $\begin{array}{l}\text { VACV } \\
5 \text { days }\end{array}$ & - & 1 & 1 & 3 & 9 & 15 & 6 & 2 & 3 & 1 & - & - \\
\hline $\mathrm{C}$ & $\begin{array}{l}\text { VACV } \\
7 \text { days }\end{array}$ & - & 1 & 1 & 10 & 9 & 8 & 8 & 4 & 1 & 1 & 1 & - \\
\hline $\mathrm{D}$ & $\begin{array}{l}\text { VACV } \\
7 \text { days }\end{array}$ & - & - & 2 & 7 & 3 & 1 & 12 & 4 & 2 & 1 & 1 & - \\
\hline E & none & - & - & 1 & 1 & 1 & 1 & 5 & 1 & 1 & - & - & - \\
\hline $\mathrm{F}$ & none & - & - & 1 & 2 & 13 & 11 & 1 & 1 & - & - & - & - \\
\hline $\mathrm{G}$ & none & 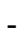 & & & - & - & - & 3 & 16 & NS & - & - & - \\
\hline $\mathrm{H}$ & none & & & 1 & 1 & 1 & 1 & 6 & 2 & NS & 1 & - & - \\
\hline
\end{tabular}

EHV: equine herpesvirus; PBMC: peripheral blood mononuclear cells; d pi: days post inoculation; VACV: valacyclovir; NS: no sample 
Table 4. Serological response in valacyclovir-treated and untreated ponies following experimental inoculation with EHV1.

\begin{tabular}{|c|c|c|c|c|c|c|c|c|}
\hline \multirow[t]{2}{*}{ Pony } & \multirow[t]{2}{*}{ Treatment } & \multicolumn{2}{|c|}{$\begin{array}{l}\text { SN titre at } \\
\text { inoculation }\end{array}$} & \multicolumn{5}{|c|}{ Complement-dependent SN titres at ... d pi } \\
\hline & & $0 \mathrm{~d}$ pi & 7 & 9 & 11 & 14 & 17 & 21 \\
\hline A & $\begin{array}{c}\text { VACV } \\
5 \mathrm{~d}\end{array}$ & $<2$ & $<2$ & 12 & 32 & 192 & 320 & 512 \\
\hline $\mathrm{B}$ & $\begin{array}{c}\text { VACV } \\
5 \mathrm{~d}\end{array}$ & $<2$ & $<2$ & $<2$ & 4 & 16 & 28 & 640 \\
\hline $\mathrm{C}$ & $\begin{array}{c}\text { VACV } \\
7 \mathrm{~d}\end{array}$ & $<2$ & $<2$ & 3 & 8 & 64 & 96 & 96 \\
\hline $\mathrm{D}$ & $\begin{array}{c}\text { VACV } \\
7 \mathrm{~d}\end{array}$ & $<2$ & $<2$ & 3 & 8 & 24 & 48 & 64 \\
\hline E & none & $<2$ & $<2$ & $<2$ & 6 & 32 & 64 & 160 \\
\hline $\mathrm{F}$ & none & $<2$ & $<2$ & $<2$ & 2 & 32 & 96 & 256 \\
\hline $\mathrm{G}$ & none & $<2$ & $<2$ & $<2$ & NS & 4 & 8 & 16 \\
\hline $\mathrm{H}$ & none & $<2$ & $<2$ & 8 & NS & 12 & 64 & 192 \\
\hline
\end{tabular}

NS: no sample 